\title{
Associations of subclinical hypocalcemia at calving with milk yield, and feeding, drinking, and standing behaviors around parturition in Holstein cows
}

\author{
P. E. Jawor, ${ }^{\star 1}$ J. M. Huzzey, ${ }^{\star}$ S. J. LeBlanc, $\dagger$ and M. A. G. von Keyserlingk ${ }^{\star 2}$ \\ *Animal Welfare Program, Faculty of Land and Food Systems, University of British Columbia, 2357 Main Mall, Vancouver, \\ British Columbia, V6T 1Z4, Canada \\ †Department of Population Medicine, Ontario Veterinary College, University of Guelph, Ontario, N1G 2W1, Canada
}

\begin{abstract}
The objectives of this study were to describe the associations of subclinical hypocalcemia with milk yield, and feeding, drinking, and resting behavior during the period around calving. Blood was sampled within $24 \mathrm{~h}$ of calving and analyzed for serum total calcium. Fifteen Holstein dairy cows were classified as having subclinical hypocalcemia (serum calcium concentration $\leq 1.8$ $\mathrm{mmol} / \mathrm{L}$, without clinical milk fever) and were matched with 15 control cows (serum calcium concentration $>1.8 \mathrm{mmol} / \mathrm{L}$ ) based on parity and presence of other diseases. Daily feeding and drinking behavior were monitored using an electronic feeding system (Insentec, BV, Marknesse, the Netherlands) and summarized by week relative to calving ( wk $-3,-2,-1,+1,+2$, and +3 ). Standing behavior was monitored from $7 \mathrm{~d}$ before until $7 \mathrm{~d}$ after calving using dataloggers. Daily milk yields were obtained for all cows up to $280 \mathrm{~d}$ in milk (DIM). These data were summarized by week for the first $4 \mathrm{wk}$ of lactation to assess short-term differences in milk yield, and were summarized into 4-wk periods to assess long-term (280 DIM) differences in milk yield between groups. Cows with subclinical hypocalcemia produced, on average, $5.7 \mathrm{~kg} / \mathrm{d}$ more milk during wk 2,3 , and 4 compared with control cows; however, only subclinically hypocalcemic cows in their third lactation sustained greater milk yields throughout 280 DIM. Despite greater milk yield during the weeks following calving, cows with subclinical hypocalcemia did not consume more water after calving and tended to have greater dry matter intake only during wk 2. However, these animals made fewer visits to the water bins during the first 2 wk after calving and tended to make fewer visits to the feed bins during wh 1 and 3 , suggest-
\end{abstract}

Received May 30, 2011.

Accepted November 16, 2011.

${ }^{1}$ Present address: Department of Immunology, Pathophysiology and Veterinary Prevention, Wroclaw University of Environmental and Life Sciences, C.K. Norwida 31, Wroclaw, 50-375, Poland.

${ }^{2}$ Corresponding author: nina@mail.ubc.ca ing that they used these resources more efficiently. Dry matter intake was, on average, $1.7 \mathrm{~kg} / \mathrm{d}$ greater during wk -2 and -1 among cows subsequently diagnosed with subclinical hypocalcemia compared with control cows but neither group was lactating during this period. Cows with subclinical hypocalcemia stood for $2.6 \mathrm{~h}$ longer during the 24 -h period before parturition, which may suggest these animals experience increased discomfort at calving; these cows spent $2.7 \mathrm{~h}$ less time standing during $d+1$. Although milk yield was greater among cows with subclinical hypocalcemia, this study controlled for the confounding effects of disease incidence; these results do not refute previous research that associates subclinical hypocalcemia with an increased risk for health disorders. The mechanisms by which subclinical hypocalcemia is associated with behavior and production require further investigation.

Key words: subclinical hypocalcemia, behavior, milk yield, Holstein dairy cow

\section{INTRODUCTION}

The onset of lactation requires that the dairy cow undergo tremendous changes in calcium homeostatic mechanisms to produce milk. During the dry period, gastrointestinal absorption is the major calcium inflow, whereas at the onset of lactation, calcium resorption from bone increases and the rate of calcium outflow to bone and feces decreases (Ramberg et al., 1970). To produce $10 \mathrm{~kg}$ of colostrum on the day of calving, $23 \mathrm{~g}$ of calcium is needed by the mammary gland (Goff and Horst, 1997). Metabolic adaptation mechanisms for calcium are not rapid enough at the onset of lactation; cows require about 1 to $2 \mathrm{~d}$ to maximize calcium inflow from the gastrointestinal tract and from bone to the mammary gland (Ramberg et al., 1970). Consequently, almost all cows experience some degree of hypocalcemia during the first days after calving but plasma calcium concentration returns to normal within 2 to $3 \mathrm{~d}$ (Ramberg et al., 1984; Horst et al., 1994).

Normal serum calcium concentrations in healthy midlactation cows range from 2.1 to $2.8 \mathrm{mmol} / \mathrm{L}$ and 
from 1.6 to $2.6 \mathrm{mmol} / \mathrm{L}$ during the week after calving among cows with no subsequent clinical disease (Quiroz-Rocha et al., 2009). Milk fever, which is a severe form of hypocalcemia, is diagnosed based on the observation of clinical signs of disease, including dull appearance, lethargy, cold ears, muscular weakness, or recumbency. The lactational incidence risk of milk fever ranges from 3 to $6 \%$ of cows of all parities, depending on the geographical region (DeGaris and Lean, 2008). Subclinical hypocalcemia can be more difficult to diagnose, because it is characterized by low serum calcium concentration in the absence of clinical milk fever symptoms. Goff (1999) and Duffield et al. (2005) proposed a serum calcium cutpoint of $\leq 1.8 \mathrm{mmol} / \mathrm{L}$ in the first week after calving, as a suitable threshold for the diagnosis of subclinical hypocalcemia. The prevalence of plasma calcium between 1.5 and $2.0 \mathrm{mmol} / \mathrm{L}$ within $48 \mathrm{~h}$ postpartum has been reported to range from 25 to $54 \%$, depending on parity (Reinhardt et al., 2011).

Cows with milk fever are at increased risk for a variety of additional health complications including dystocia, retained placenta, and metritis (Erb et al., 1985). Milk fever has also been associated with immune suppression by impairing the activity of mononuclear blood cells (Kimura et al., 2006). The relationships between subclinical hypocalcemia and health are less consistent. As described earlier, Duffield et al. (2005) found that cows with subclinical hypocalcemia but not clinical milk fever, had a greater risk of culling in early lactation than cows with calcium concentrations above the suggested $1.8 \mathrm{mmol} / \mathrm{L}$ threshold. However, studies disagree on the association of subclinical hypocalcemia with increased risk of displaced abomasum. Massey et al. (1993) found that the risk of left abomasum displacement (LDA) was almost 5 times higher among cows with subclinical hypocalcemia. However, LeBlanc et al. (2005) reported no relationship between serum calcium concentrations and the subsequent incidence of LDA and hypothesized that subclinical hypocalcemia may be symptomatic of inadequate prepartum feed intake, which leads to other risks for LDA, such as elevated NEFA concentration (Reinhardt et al., 2011) and subclinical ketosis.

Reports on the relationship between hypocalcemia and milk yield are inconsistent. Rajala-Schultz et al. (1999) reported that although cows with milk fever produced, on average, more milk than healthy cows, milk fever was associated with production losses between wk 4 to 6 of lactation when using the cows' own milk yield during midlactation as the reference level. In contrast, Østergaard and Larsen (2000) evaluated cows with milk fever and with subclinical hypocalcemia and found that low total plasma calcium at calving was not a risk factor for decreased milk yield.
Understanding behavioral characteristics of cows that have subclinical hypocalcemia after calving may help to facilitate improvements in treatment, transition cow management, and ultimately health. Currently, producers can readily identify animals with milk fever through the observation of overt clinical signs, including dull appearance, lethargy, cold ears, or a down cow; subclinical hypocalcemia may be associated with more subtle changes in behavior, such as changes in intake or resting behavior. Previous work has shown that changes in behavior, such as time spent at the feed bunk or changes in lying bouts, may be an early indicator of risk for dystocia (Proudfoot et al., 2009), subclinical ketosis (Goldhawk et al., 2009), and metritis (Huzzey et al., 2007). The objectives of this study were to describe the associations of subclinical hypocalcemia at calving with 1) milk yield and 2) feeding, drinking, and resting behavior around parturition.

\section{MATERIALS AND METHODS}

\section{Animals, Housing, and Diet}

The study was conducted at the University of British Columbia's Dairy Education and Research Centre (Agassiz, BC, Canada). All animals were cared for according to the guidelines of the Canadian Council on Animal Care (1993). In total, 32 primiparous and 69 multiparous (parity $=3.2 \pm 1.3$, mean \pm SD) Holstein dairy cows were observed from 3 wk before until 3 wk after calving. Experimental cows were housed in pre- and postpartum group pens, each maintained at 20 cows per pen. The experimental pens provided 20 freestalls, 12 Insentec feed bins, and 2 Insentec water troughs (Insentec BV, Marknesse, Holland). The Insentec feeding system is described in detail by Huzzey et al. (2007). Cows entered the prepartum pen $25 \pm 2 \mathrm{~d}$ before their expected calving date. They were moved to the maternity pen when they showed physical signs of imminent calving (i.e., udder enlargement, milk letdown, and relaxation of tail ligament). The maternity pen consisted of a sand-bedded pack with 6 Insentec feed bins and 1 Insentec water trough. A maximum of 2 cows were kept in the maternity pen at any given time and cows were moved to the postpartum pen within 24 $\mathrm{h}$ after calving where they were monitored for an additional $21 \mathrm{~d}$. Cows in the postpartum pen were milked twice daily at approximately 0700 and 1700 h. Daily milk yields were recorded for each cow until she was dried-off, left the herd, or reached 305 DIM, whichever came first.

Cows had ad libitum access to feed with fresh feed being delivered to the feed bins twice daily at approximately 0800 and $1600 \mathrm{~h}$; orts were removed from the 
bins each morning before fresh feed delivery and the bins cleaned. Samples of the pre- and postpartum TMR were collected on Monday, Wednesday, and Friday of each week and pooled into monthly composite samples. Samples were dried at $60^{\circ} \mathrm{C}$ over $2 \mathrm{~d}$ to determine DM content and then sent for nutrient analysis to Cumberland Valley Analytical Services Inc. (Maugansville, MD). Prepartum and maternity diets consisted of $21.3 \%$ corn silage, $42.8 \%$ alfalfa hay, and $35.9 \%$ concentrate and mineral mix on a DM basis [DM: $50.8 \pm 1.2 \%$, and on a $\mathrm{DM}$ basis (mean $\% \pm \mathrm{SD}$ ), $\mathrm{CP}: 14.4 \pm 1.0$, ADF: $35.0 \pm 2.7, \mathrm{NDF}: 45.6 \pm 2.6$, Ca: $0.80 \pm 0.06, \mathrm{P}: 0.30$ $\pm 0.02, \mathrm{Mg}: 0.34 \pm 0.06, \mathrm{~K}: 1.48 \pm 0.08, \mathrm{Na}: 0.20 \pm$ 0.01 , and $\mathrm{NE}_{\mathrm{L}}: 1.40 \pm 0.1 \mathrm{Mcal} / \mathrm{kg}$ ). The postpartum TMR consisted of $21.3 \%$ grass silage, $14.7 \%$ corn silage, $12.3 \%$ alfalfa hay, and $51.7 \%$ concentrate and mineral mix on a DM basis (DM: $51.1 \pm 1.8 \%$, and on a $\%$ DM basis, CP: $17.7 \pm 1.0, \mathrm{ADF}: 23.7 \pm 1.4$, NDF: $36.1 \pm$ 1.8, Ca: $0.93 \pm 0.08, \mathrm{P}: 0.39 \pm 0.02, \mathrm{Mg}: 0.31 \pm 0.03$, $\mathrm{K}: 1.71 \pm 0.22$, Na: $0.22 \pm 0.01$, and $\mathrm{NE}_{\mathrm{L}}: 1.66 \pm 0.02$ $\mathrm{Mcal} / \mathrm{kg})$.

\section{Serum Analysis for Determination of Subclinical Hypocalcemia Status}

A blood sample was collected for each cow within 24 $\mathrm{h}$ after calving. This sample was always taken before the herd's preventive treatment protocol for hypocalcemia that involved providing $500 \mathrm{~mL}$ of calcium borogluconate (23\% wt/vol, Vétoquinol, Bimeda-MTC Animal Health Inc., Cambridge, Ontario) once subcutaneously to cows of parity 3 or higher immediately following calving. Blood was collected from the coccygeal vessel into a $10-\mathrm{mL}$ evacuated sterile serum tube (Vacutainer, Venous Blood Collection Red Top Tubes; BD Biosciences, Franklin Lakes, NJ), allowed to clot at room temperature for up to $3 \mathrm{~h}$, and then was centrifuged at $1,400 \times g$ for $10 \mathrm{~min}$. Serum was harvested and frozen at $-20^{\circ} \mathrm{C}$ for later analysis. Serum samples were sent to the University of Guelph Animal Health Laboratory (Ontario, Canada) and total calcium concentration was measured (Roche diagnostics GmbH, Manheim, Germany) using an automated wet chemistry analyzer (Roche Hitachi 911 Chemistry Analyzer; Roche Diagnostics, Indianapolis, IN).

\section{Subclinical Hypocalcemia Classification and Cow Participation in Study}

Of the original 101 cows enrolled in the study a subset of animals was established based on health status for statistical analyses. Two cows did not have blood samples taken within $24 \mathrm{~h}$ after calving and so were removed from the study. A cow was classi- fied as having subclinical hypocalcemia when serum calcium concentration was $\leq 1.8 \mathrm{mmol} / \mathrm{L}$ (Goff, 1999; Duffield et al., 2005) and clinical milk fever was not observed. Although cows with milk fever have a much lower calcium concentration nadir than do healthy cows (Kimura et al., 2006), the observed ranges of serum calcium between calving and 2 DIM overlap between clinically normal and cows with milk fever. However, the chosen cut-point is at the midpoint of the range for subclinical hypocalcemia proposed by Reinhardt et al. (2011). Of 99 cows, 33 were identified as hypocalcemic on the day of calving and 66 were identified as having normal calcium concentrations (control cows: calcium $>1.8 \mathrm{mmol} / \mathrm{L}$ ). Of the 33 hypocalcemic cows, 5 were not included in the statistical analyses due to the presence of additional health complications that could have significantly altered behavior and intake around calving (i.e., clinical milk fever, severe vulva infection, lameness, and damaged udder). The remaining 28 subclinically hypocalcemic cows were pair matched with a control cow first based on parity and then, where possible, on the incidence of other health disorders (mild or severe metritis, fever, or mastitis). Subclinically hypocalcemic cows in second, third, fourth, fifth, sixth, and seventh lactation numbered $5,8,6,6,2$, and 1 , respectively. Among cows in the higher lactations (parity $\geq 5$ ), 2 or fewer pairs could be formed after balancing with control animals for parity and health. Because the effect of parity was to be included in the statistical models, cows of parity 5 or greater were excluded due to too few observations to allow for meaningful statistical interpretation. After matching animals based on the criteria outlined above, 5 pairs were available for each of the second, third, and fourth lactations (15 subclinically hypocalcemic cows balanced with 15 control cows) and these animals were used for all further analyses. The number of events of mild metritis, severe metritis, fever, and mastitis in the subclinical hypocalcemia group was $2,2,1$, and 2 , respectively, and in the control group was $3,2,1$, and 0 , respectively.

\section{Behavior and Intake Data Collection}

An electronic feeding system (Insentec BV) validated by Chapinal et al. (2007) was used to continuously monitor feeding and drinking behavior as well as individual feed and water intakes for all experimental cows. Each cow had a unique passive transponder (High Performance ISO Half Duplex Electronic ID Tag; Allflex Inc., St. Hyacinthe, Quebec, Canada) attached to her ear tag. When a cow approached the bin, an antenna detected the cows' transponder and the head gate opened, allowing the cow access to feed or water. At the time the gate opened, the Insentec system recorded the time 
and the initial weight in the bin. When a cow exited the bin, the head gate closed and the system again recorded the time and the weight in the bin. These data were used to record the duration of each visit to the bin and the amount of feed or water consumed. Only visits during which cows consumed feed or water were included in the analyses. Daily as-fed intakes recorded by the Insentec system were corrected for the DM content of the feed.

Standing behavior data were collected using modified dataloggers (Gemini Dataloggers Ltd., Chichester, UK), validated by O'Driscoll et al. (2008). The dataloggers were fitted on the hind leg of each cow upon entering the prepartum group and recorded leg orientation (horizontal vs. vertical) at 1-min intervals. Loggers were switched to the opposite hind leg weekly to download stored data and prevent sores from developing on the leg where the logger was attached. Loggers were removed $21 \mathrm{~d}$ after calving. The data collected were used to quantify total daily standing and lying time and the number of times cows transitioned from standing to lying positions (i.e., standing bouts).

\section{Statistical Analysis}

Statistical analyses were performed with SAS (version 9.1; SAS Institute, 2003) using cow $(\mathrm{n}=30)$ as the experimental unit. Feeding, drinking, and standing events were screened for normality and the presence of outliers by visual assessment of the distributions using PROC UNIVARIATE. Extreme outliers were defined as observations that lay more than 3 times the interquartile range from the first or third quartile of the data set. Of 56,795 feeding events, $2.16 \%$ were identified as extreme outliers. Of 12,070 drinking events, $5.8 \%$ were identified as extreme outliers and from 1,041 standing events, $0.1 \%$ were identified as extreme outliers. These observations were removed from the study.

Due to the well-described differences in behavior and intake and differences in risk of disease during the weeks leading up to and after calving, the associations of subclinical hypocalcemia status with feeding and drinking behavior were tested separately by period. Six experimental periods were defined for the analyses based on the week relative to calving: wk $-3(\mathrm{~d}-21$ to $-15)$, wk -2 (d -14 to -8$)$, wk -1 (d -7 to -1$)$, wk 1 (d 0 to 7 ), wk 2 (d 8 to 14), and wk 3 (d 15 to 21 ). Differences in DMI, water intake, number of feed and water visits, and feeding and drinking rates between control cows and those with subclinical hypocalcemia were analyzed using PROC MIXED. A Type I analysis was used for the fixed effects modeled in the following order: parity, calcium status, and the parity $\times$ calcium status interaction. If an interaction was detected $(P<$ $0.05)$, data were stratified by parity.

Previous work suggests that significant changes in standing behavior occur during the 24-h period before parturition as part of normal behavioral adaptations to calving (Huzzey et al., 2005). To capture potential differences in standing behavior between the control cows and those with subclinical hypocalcemia during the period around calving, standing time and standing bouts were analyzed by day beginning $7 \mathrm{~d}$ before calving until $7 \mathrm{~d}$ after calving. Standing behavior data were adjusted according to the actual time of calf delivery for each cow (i.e., day -1 represented the 24 -h period before calving, whereas d 0 represented the 24 -h period after calf delivery). A total of 3 cows from the control group and 4 cows from the subclinical hypocalcemic group were removed from the standing behavior analyses due to missing or insufficient data on standing activity around the calving period. Differences in standing time and standing bouts between control cows $(\mathrm{n}=$ $12)$ and those with subclinical hypocalcemia $(n=11)$ were analyzed using PROC MIXED with day modeled as a repeated measure. A Type I analysis was used for the fixed effects modeled in the following order: parity, day, calcium status, and the day $\times$ calcium status and parity $\times$ calcium status interaction. If an interaction was detected $(P<0.05)$, data were stratified by the relevant term.

Proc GLM was used to compare the average 305-d milk yield from the previous lactation of each experimental group. For the current lactation, the shortest lactation length was $281 \mathrm{~d}$; therefore, to compare long-term milk yield between groups, the yield of all cows was censored beyond 280 DIM. Ten periods were defined for the long-term analysis of milk yield based on 4 -wk $(28 \mathrm{~d})$ increments of the lactation [i.e., period 1 (2 to 28 DIM), period 2 (29 to 56 DIM), period 3 (57 to 84 DIM), . . . period 10 (253-280 DIM)]. Daily milk yields were used to generate an average daily yield per cow during each of these experimental periods. To explore the short-term relationship between milk yield (first 28 DIM) and presence of subclinical hypocalcemia within 24-h after calving, 4 periods were defined based on week relative to calving: wk 1 (d 2 to 7 ), wk 2 (d 8 to 14 ), wk 3 (d 15 to 21 ), and wk 4 (d 22 to 28 ). Due to inconsistencies in the manual reporting of milk yield during d 0 and 1 by farm staff, these days were excluded from the milk production analyses. A Type I analysis with PROC MIXED was used to evaluate the fixed effects modeled in the following order: parity, period, calcium status, and the interactions parity $\times$ calcium status and period $\times$ calcium status. Cow was treated as a random effect and period as a repeated 
measure. If an interaction was detected $(P<0.05)$, data were stratified by the relevant term.

\section{RESULTS}

\section{Calcium Concentration}

Cows with subclinical hypocalcemia had an average calcium concentration that was $0.51 \mathrm{mmol} / \mathrm{L}$ lower than that of the control cows $[1.54(1.21-1.80) \pm 0.17$ vs. $2.05(1.81-2.61) \pm 0.25 \mathrm{mmol} / \mathrm{L}$; mean (range) \pm $\mathrm{SD}]$.

\section{Milk Production}

No differences were observed between groups in their 305 -d milk yield in the previous lactation (10,999 vs. $11,005 \mathrm{~kg}$, for the control and subclinical hypocalcemia groups, respectively; $P=0.99$ ), nor a significant parity $\times$ calcium status interaction $(P=0.11)$. An effect of calcium status on milk yield during the first $4 \mathrm{wk}$ of lactation $(P=0.01)$ was observed and also a period $\times$ calcium status interaction $(P=0.02)$. Subsequent stratification by period revealed that cows with subclinical hypocalcemia produced, on average, $6 \mathrm{~kg} / \mathrm{d}$ more milk during wk 2,3 , and 4 compared with control cows $(P \leq 0.04$; Figure 1$)$. A parity $\times$ calcium status interaction during wk $2(P=0.03)$ revealed that milk yield was only greater among third-lactation cows with subclinical hypocalcemia $(P=0.003)$. For the long-term analysis of milk yield, a parity $\times$ calcium status interaction was detected $(P=0.002)$. When the data were stratified by parity and differences in milk yield between experimental groups, differences were only detected among third-lactation cows $(P=0.01)$ and these differences were consistent across each of the 10 experimentally defined periods due to the lack of a period $\times$ calcium status interaction $(P=0.17)$. Cows in their third lactation with subclinical hypocalcemia produced, on average, $6.4 \mathrm{~kg} / \mathrm{d}$ more milk across the 10 periods compared with third-lactation control cows (Figure 2).

\section{Drinking and Feeding Behavior}

Cows with subclinical hypocalcemia visited the water bins less frequently than control cows during wk 1 and 2 after calving (Figure 3A; $P \leq 0.05$ ) and tended to visit the feed bins fewer times during wh 1 and 3 relative to calving (Figure 3B; $P \leq 0.14$ ) compared with control cows.

Water intake was not different between control cows and those with subclinical hypocalcemia at any period relative to calving (Figure $4 \mathrm{~A} ; P \geq 0.2$ ). Dry matter

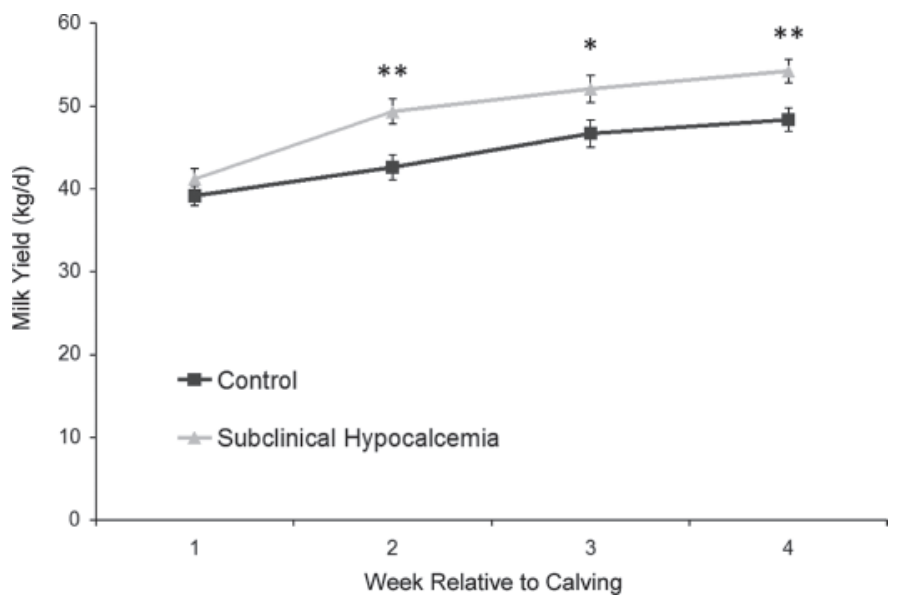

Figure 1. Least squares means $( \pm \mathrm{SE})$ milk yield during the first 4 wk of lactation for cows with $(\boldsymbol{\Lambda}, \mathrm{n}=15)$ and without $(\boldsymbol{\square}, \mathrm{n}=15)$ subclinical hypocalcemia (serum total calcium $\leq 1.8 \mathrm{mmol} / \mathrm{L}$ within 24 $\mathrm{h}$ after calving). ${ }^{* *} P \leq 0.01 ;{ }^{*} P \leq 0.05$.

intake was greater during wk -2 and $-1(P \leq 0.03)$ in cows that subsequently had subclinical hypocalcemia and tended to be greater during wk $2(P=0.09)$ compared with control cows (Figure 4B). For both the analysis of water intake and DMI, no parity $\times$ calcium status interactions were detected $(P \geq 0.48$ and $P \geq$ 0.30 , respectively). No differences in feeding or drinking rate occurred between control cows and those with subclinical hypocalcemia at any period relative to caving (Table $1 ; P \geq 0.3$ ).

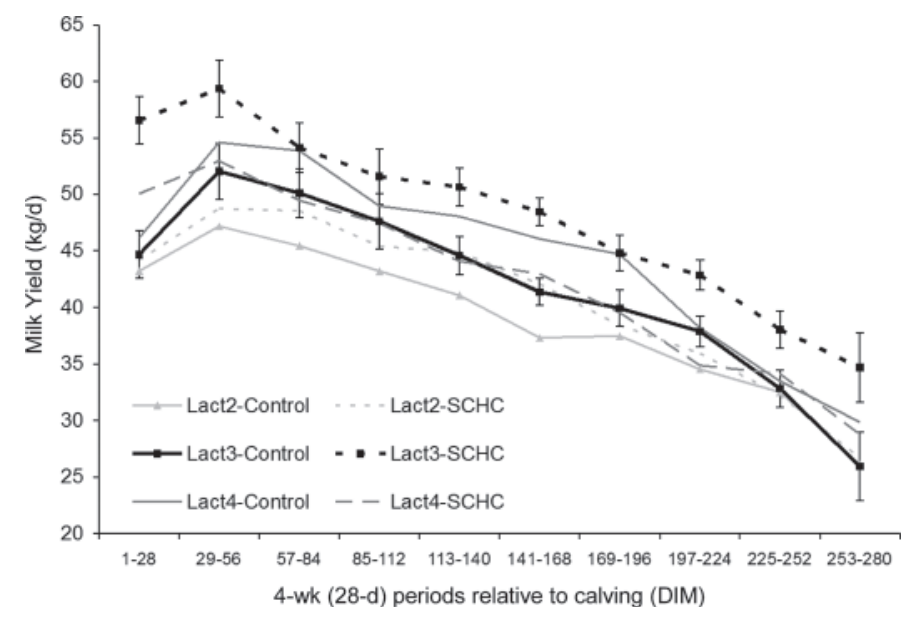

Figure 2. Least squares means $( \pm \mathrm{SE})$ daily milk yield during ten 4 -wk periods relative to calving for third-lactation (Lact) cows with ($--, \mathrm{n}=5)$ and without $(-, \mathrm{n}=5)$ subclinical hypocalcemia (SCHC: serum total calcium $\leq 1.8 \mathrm{mmol} / \mathrm{L}$ within $24 \mathrm{~h}$ after calving). Data for second- and fourth-lactation cows are also shown as a reference; however, milk yield was not statistically different between experimental groups among these parities. 

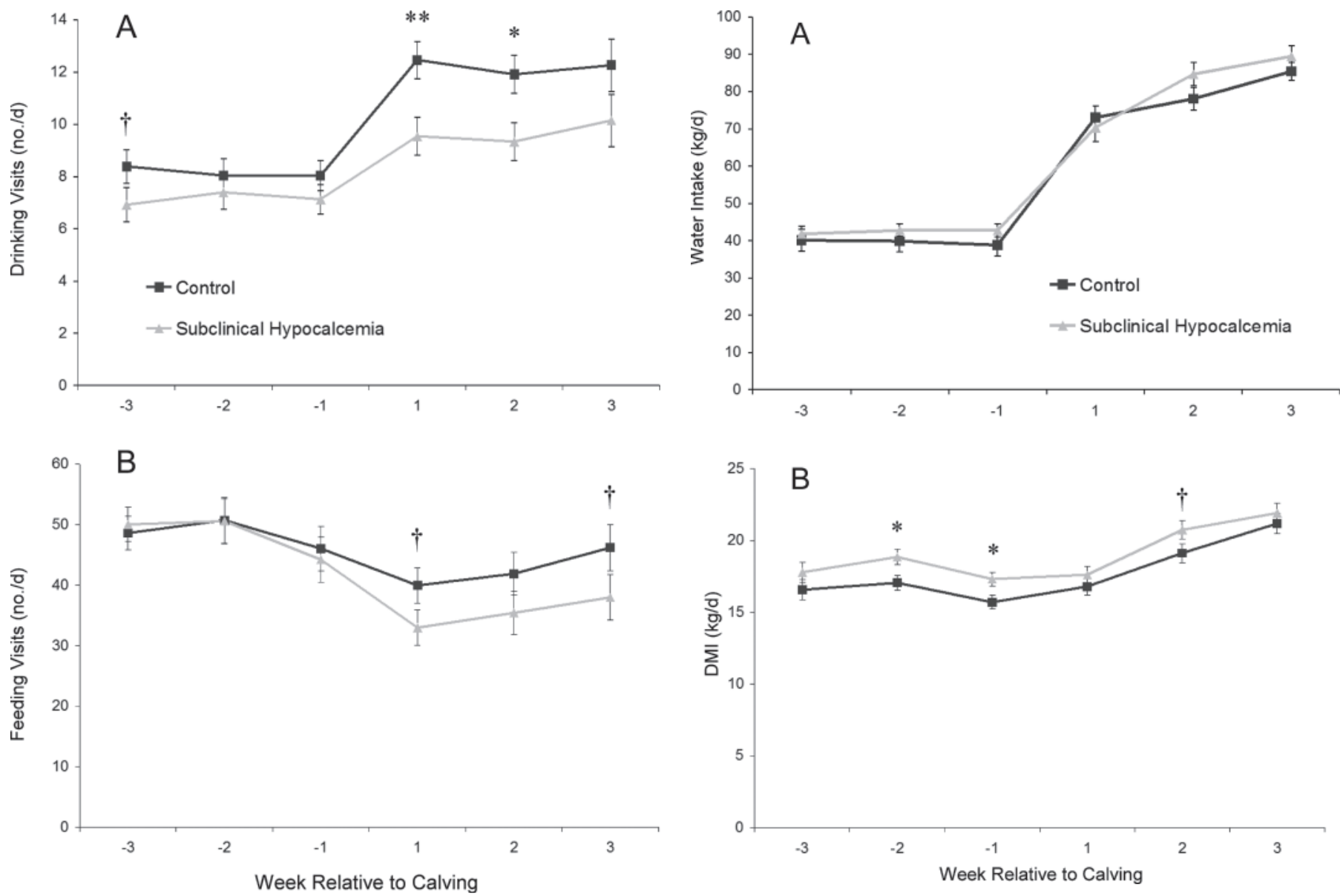

Figure 3. Number $(\mathrm{LSM} \pm \mathrm{SE})$ of daily visits to the water $(\mathrm{A})$ and feeding (B) bins for cows with $(\boldsymbol{\Lambda}, \mathrm{n}=15)$ and without $(\mathbf{\square}, \mathrm{n}=15)$ subclinical hypocalcemia (serum total calcium $\leq 1.8 \mathrm{mmol} / \mathrm{L}$ within $24 \mathrm{~h}$ after calving) during the peripartum period. ${ }^{* *} P \leq 0.01 ;{ }^{*} P \leq$ $0.05 ; \dagger P \leq 0.1$

\section{Standing Behavior}

No differences were observed in the average number of daily standing bouts between control cows and those with subclinical hypocalcemia during the $7 \mathrm{~d}$ before and after calving (prepartum: 12.2 vs. 12.0 bouts, post-

Figure 4. Least squares means $( \pm \mathrm{SE})$ daily water intake $(\mathrm{A})$ and DMI (B) for cows with $(\mathbf{\Lambda}, \mathrm{n}=15)$ and without $(\boldsymbol{\square}, \mathrm{n}=15)$ subclinical hypocalcemia (serum total calcium $\leq 1.8 \mathrm{mmol} / \mathrm{L}$ within $24 \mathrm{~h}$ after calving) during the peripartum period. ${ }^{*} P \leq 0.05 ; \dagger P \leq 0.1$.

partum: 10.7 vs. 10.3 bouts for control and subclinical hypocalcemia cows, respectively; $P=0.90)$. The initial analysis of standing time between the groups revealed a day $\times$ calcium status interaction $(P=0.01)$, so the data were stratified by day. Cows with subclinical hypocalcemia on $\mathrm{d} 0$ spent more time standing on $\mathrm{d}-1$ (16.5 vs. $13.9 \mathrm{~h} ; P=0.03)$ and tended to spend less

Table 1. Least squares means $( \pm \mathrm{SE})$ daily drinking and feeding rate for subclinical (SC) hypocalcemic cows ( $\mathrm{n}=15$, serum total calcium $\leq 1.8 \mathrm{mmol} / \mathrm{L}$ within $24 \mathrm{~h}$ after calving) and control cows $(\mathrm{n}=15$, calcium $>1.8$ $\mathrm{mmol} / \mathrm{L}$ ) during the peripartum period

\begin{tabular}{lcccccc}
\hline & \multicolumn{7}{c}{ Period } \\
\cline { 2 - 6 } Item & $\mathrm{wk}-3$ & $\mathrm{wk}-2$ & $\mathrm{wk}-1$ & $\mathrm{wk}+1$ & $\mathrm{wk}+2$ & $\mathrm{wk}+3$ \\
\hline Drinking rate $(\mathrm{kg} / \mathrm{min})$ & & & & & \\
$\quad$ Control & $6.1 \pm 0.9$ & $6.0 \pm 0.7$ & $6.0 \pm 0.7$ & $6.8 \pm 0.7$ & $6.8 \pm 0.8$ & $7.2 \pm 0.8$ \\
$\quad$ SC hypocalcemia & $5.6 \pm 0.9$ & $5.6 \pm 0.9$ & $6.0 \pm 0.9$ & $6.8 \pm 0.9$ & $6.8 \pm 0.9$ & $7.5 \pm 0.9$ \\
Feeding rate (g/min) & & & & & \\
$\quad$ Control & $84.3 \pm 4$ & $87.9 \pm 4$ & $92.4 \pm 4$ & $111.8 \pm 4$ & $104.6 \pm 4$ & $101.9 \pm 4$ \\
SC hypocalcemia & $78.7 \pm 4$ & $83.6 \pm 4$ & $88.9 \pm 5$ & $112.3 \pm 4$ & $105.9 \pm 4$ & $103.4 \pm 4$ \\
\hline
\end{tabular}




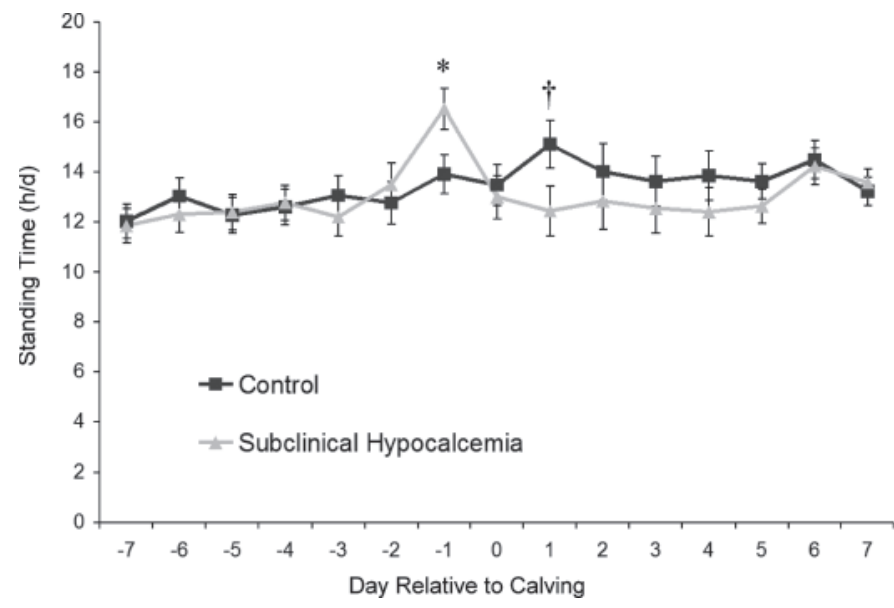

Figure 5. Least squares means $( \pm \mathrm{SE})$ standing time $(\mathrm{h} / \mathrm{d})$ for cows with $(\mathbf{\Lambda}, \mathrm{n}=12)$ and without $(\mathbf{\square}, \mathrm{n}=11)$ subclinical hypocalcemia (serum total calcium $\leq 1.8 \mathrm{mmol} / \mathrm{L}$ within $24 \mathrm{~h}$ after calving) during 7 $\mathrm{d}$ before and after calving. Day 0 represents the 24 -h period following calving. ${ }^{*} P \leq 0.05 ; \dagger P \leq 0.1$.

time standing during $\mathrm{d}+1$ (12.4 vs. $15.1 \mathrm{~h} ; P=0.07)$ compared with control cows (Figure 5).

\section{DISCUSSION}

Among cows that were identified with subclinical hypocalcemia within $24 \mathrm{~h}$ of calving, milk yield was greater during wk 2 (third-lactation cows only), 3 , and 4 relative to calving. Further, third-lactation cows with subclinical hypocalcemia $(\leq 1.8 \mathrm{mmol} / \mathrm{L})$ shortly after calving had greater milk yield throughout the first 280 DIM relative to third-lactation cows with calcium concentrations above $1.8 \mathrm{mmol} / \mathrm{L}$. Although the sample size in this study was low, comparison groups were carefully balanced according to health status (mild or severe metritis, fever, and mastitis) and parity so that differences in milk yield and behavior could more confidently be discussed relative to differences in calcium status, rather than other extenuating factors. After controlling for disease and parity, low total calcium concentration $24 \mathrm{~h}$ after calving does not appear to be a risk factor for decreased yield. This supports the claim of Østergaard and Larsen (2000), although these researchers did not observe the increase in yield that was observed in the current study. It is unclear what the mechanism may be to explain the association of briefly worse hypocalcemia with greater milk yield for several weeks or the whole lactation. Cows with greater capacity for milk production may also be prone to greater net loss of calcium just after calving, yet be able to cope with this transient metabolic challenge. A weakness of this study is that the study herd had a preventive treatment protocol for hypocalcemia that involved all cows (parity 3 or higher) receiving a bottle of calcium subcutaneously immediately after parturition. Although blood samples for the calcium analysis were always taken before the exogenous calcium was given, this preventive program may have helped those cows utilizing more endogenous calcium reserves to avoid clinical milk fever and maintain high milk yield. However, this dose and route of calcium in Holstein cows would only raise blood calcium modestly for $4 \mathrm{~h}$ (Goff, 1999).

These results do not refute the undesirable effects of clinical milk fever or the association of subclinical hypocalcemia with worse measures of energy status (e.g., increased NEFA; Reinhardt et al., 2011) or the inconsistent association with risk of displaced abomasum (Massey et al., 1993; LeBlanc et al., 2005). Rather, the results of this study underline the association of subclinical hypocalcemia with increased milk yield in early lactation when comparison groups are balanced for disease or health status.

Cows with subclinical hypocalcemia had greater DMI during the 2 wk leading up to calving; however, after calving (when milk production was increased), a tendency for increased DMI only occurred during wk 2 . Increased DMI after calving may suggest associations among regulators of feed intake and calcium metabolism. Increased milk yield after calving is expected to be associated with increased DMI (NRC, 2001); however, increased prepartum intake observed in the cows with subsequent subclinical hypocalcemia could not be explained by an increase in nutrient requirements to support increased milk yield, as these cows were not yet lactating. It is unclear what mediators are responsible for this observed increase in intake; however, intake level could be related to non-nutritional factors such as social dominance or a cow's level of success at competing for access to the feed bunk.

No differences in water intake were detected between cows with and without subclinical hypocalcemia at calving. Increased milk yield is typically associated with an increase in free water intake (drinking); however, cattle acquire, on average, $17 \%$ of their requirements from water obtained in the feed they are consuming (NRC, 2001). Although cows with subclinical hypocalcemia did not have greater water intakes compared with control cows despite their higher level of milk yield, they may have achieved their increased water needs through an increase in DMI.

Cows with subclinical hypocalcemia made fewer visits to both the feed and water troughs during the weeks following calving; however, no differences existed in the number of visits to the feeder during the weeks leading up to calving. These results suggest that cows with subclinical hypocalcemia may use feeding and drinking resources more efficiently during the period 
following calving; they acquired their water and feed requirements in fewer visits to the bins. This increase in efficiency of resource use has previously been described for dairy cows facing health challenges during the postpartum period. The correlation coefficient between feeding time and DMI during the 3 -wk period after calving among cows with severe metritis was higher than the coefficient for cows without metritis $(\mathrm{r}=0.90$ vs. 0.82; Huzzey et al., 2007). These results highlight the importance of ensuring that cows have adequate access (via a low stocking density) to feeding and drinking areas during the period following calving so that they can meet their nutrient requirements, allowing for variation in efficiency of use of feeding and drinking resources between subgroups of cows.

Low plasma calcium concentrations can affect contraction of calcium-dependent smooth muscle and skeletal muscle (Murray et al., 2008) and, thus, could compromise physical movements to and from the feed or water bins. Muscle weakness due to calcium deficiency may explain the observed decrease in the number of visits to the feed and water bins and the decrease in standing time following calving among cows with subclinical hypocalcemia. Alternatively, these differences in behavior might also be attributed to social dominance or genetic potential for milk production rather than low calcium concentrations directly. For example, high-producing cows may be less likely to submit to competition (i.e., be displaced) at the feed or water trough or lying stalls; this would allow them adequate opportunity to eat or drink to support their increased nutrient requirements and to retain lying stalls for longer resting times. Being more competitive at the bunk has been shown to be associated with healthier cows (Huzzey et al., 2007; Goldhawk et al., 2009) and may, therefore, also play a role in a cow's ability to achieve high milk yield.

Cows with subclinical hypocalcemia spent almost $3 \mathrm{~h}$ longer standing during the 24 -h period preceding parturition compared with control cows. It is difficult to explain these acute differences in standing behavior based on subsequent level of milk production. These differences may have been more directly associated with reduced circulating calcium concentrations during the period around parturition. Huzzey et al. (2005) reported that standing time between $\mathrm{d}-1$ to $\mathrm{d}+1$ relative to calving is higher than at other times during the transition period and that the number of standing bouts (transitions from lying to standing) almost double between $\mathrm{d}-1$ and the day of calving compared with all other times relative to calving. These behavioral changes are typical and attributed to the discomfort associated with labor and the process of parturition. Calcium is essential for proper myometrial smooth muscle cell contractility (López Bernal, 2003).
In calcium-deficient animals, uterine contractions during the final stages of labor may be weaker, thus prolonging the calving process. Prolonged labor attributed to hypocalcemia and the corresponding prolonged discomfort could potentially explain the greater standing times; however, this hypothesis is only speculative. An alternative theory for the greater time spent standing during the 24-h before parturition could be that these animals, due to their increased milk yield postpartum, had greater udder fill before parturition, which may have made resting during this time more uncomfortable and, thus, resulted in longer standing times.

The present data should be built upon with studies that include measurements of plasma calcium throughout the transition period, including daily samples during the days around calving. These studies should also include sufficient numbers of animals so that behavioral changes associated with subclinical hypocalcemia at calving might be described for cows with different subsequent health outcomes (disease or culling risk) or milk production levels.

\section{CONCLUSIONS}

Dairy cattle with subclinical hypocalcemia (serum calcium $\leq 1.8 \mathrm{mmol} / \mathrm{L}$ ) during the 24 -h period following calving did not exhibit production or behavioral changes that would classically be associated with poor health. Cows with subclinical hypocalcemia produced almost $6 \mathrm{~kg} / \mathrm{d}$ more milk during wk 2 (third-lactation cows only), wk 3 and 4 after calving compared with control cows and had greater DMI during the 2-wk period before calving. Dry matter intake also tended to be greater among cows with subclinical hypocalcemia during wk 2 after calving. Although no differences existed in water intake between the experimental groups, cows with subclinical hypocalcemia visited both the water and feed bins less frequently than did the control cows; this may suggest that they use their time more efficiently at these resources, allowing them to maintain the same level of water intake and greater feed intake in fewer visits. Standing time was almost $3 \mathrm{~h}$ longer during the 24-h period before calving among cows with subclinical hypocalcemia; this may suggest these animals experience additional discomfort associated with labor and highlights the importance of ensuring that cows have a well-bedded and comfortable resting area during parturition. These results do not refute the undesirable effects of clinical milk fever or studies that suggest subclinical hypocalcemia may be a potential health risk for transition cows. Comparison groups in this study (control vs. subclinical hypocalcemic cows) were balanced based on health status and so this study underlines the association of subclinical hypocalcemia 
with increased milk yield and changes in behavior in early lactation in the absence of the confounding effects of disease incidence. The mechanisms by which subclinical hypocalcemia is associated with behavior, disease risk, and production require further investigation.

\section{ACKNOWLEDGMENTS}

The authors thank Katy Proudfoot and Dan Weary of the University of British Columbia Animal Welfare Program (Vancouver, BC, Canada) for the numerous discussions that took place during the preparation of this manuscript. P. E. Jawor thanks the Dekaban Foundation for Visiting Polish Scholars to the University of British Columbia (Vancouver, BC, Canada). The Animal Welfare Program is funded by Canada's Natural Sciences and Engineering Research Council (NSERC) Industrial Research Chair Program (Ottawa, ON, Canada) with industry contributions from the Dairy Farmers of Canada (Ottawa, ON, Canada), Westgen Endowment Fund (Milner, BC, Canada), Pfizer Animal Health (Kirkland, QC, Canada), BC Cattle Industry Development Fund (Kamloops, BC, Canada), the BC Milk Producers (Burnaby, BC, Canada), BC Dairy Foundation (Burnaby, BC, Canada), BC Dairy Education and Research Association (Abbotsford, BC, Canada), and Alberta Milk (Edmonton, AB, Canada).

\section{REFERENCES}

Canadian Council on Animal Care. 1993. Guide to the Care and Use of Experimental Animals. Vol. 1. E. D. Olfert, B. M. Cross, and A. A. McWilliam, ed. CCAC, Ottawa, Ontario, Canada.

Chapinal, N., D. M. Veira, D. M. Weary, and M. A. G. von Keyserlingk. 2007. Validation of a system for monitoring individual feeding and drinking behavior and intake in group housed cattle. J. Dairy Sci. 90:5732-5736.

DeGaris, P. J., and I. J. Lean. 2008. Milk fever in dairy cows: A review of pathophysiology and control principles. Vet. J. 176:58-69.

Duffield, T., S. LeBlanc, and K. Leslie. 2005. Impact of subclinical metabolic disease on risk of early lactation culling. J. Dairy Sci. 88(Suppl. 1):199-200. (Abstr.)

Erb, H. N., R. D. Smith, P. A. Oltenacu, C. L. Guard, R. B. Hillman, P. A. Powers, M. C. Smith, and M. E. White. 1985. Path model of reproductive disorders and performance, milk fever, mastitis, milk yield and culling in Holstein cows. J. Dairy Sci. 68:3337-3349.

Goff, J. P. 1999. Treatment of calcium, phosphorus and magnesium balance disorders. Vet. Clin. North Am. Food Anim. Pract. 15:619-639.
Goff, J. P., and R. L. Horst. 1997. Physiological changes at parturition and their relationship to metabolic disorders. J. Dairy Sci. $80: 1260-1268$.

Goldhawk, C., N. Chapinal, D. M. Veira, D. M. Weary, and M. A. G. Keyserlingk. 2009. Prepartum feeding behavior is an early indicator of subclinical ketosis. J. Dairy Sci. 92:4971-4977.

Horst, R. L., J. P. Goff, and T. A. Reinhardt. 1994. Calcium and vitamin D metabolism in the dairy cow. J. Dairy Sci. 77:1936-1951.

Huzzey, J. M., M. A. G. Keyserlingk, and D. M. Weary. 2005. Changes in feeding, drinking, and standing behavior of dairy cows during the transition period. J. Dairy Sci. 88:2454-2461.

Huzzey, J. M., D. M. Veira, D. M. Weary, and M. A. G. Keyserlingk. 2007. Prepartum behavior and dry matter intake identify dairy cows at risk for metritis. J. Dairy Sci. 90:3220-3233.

Kimura, K., T. A. Reinhardt, and J. P. Goff. 2006. Parturition and hypocalcaemia blunts calcium signals and immune cells of dairy cattle. J. Dairy Sci. 89:2588-2595.

LeBlanc, S. J., K. E. Leslie, and T. F. Duffield. 2005. Metabolic predictors of displacement abomasum in dairy cattle. J. Dairy Sci. 88:159-170.

López Bernal, A. 2003. Mechanisms of labour-Biochemical aspects. BJOG 110:39-45.

Massey, C. D., C. Wang, G. A. Donovan, and D. K. Beede. 1993. Hypocalcemia at parturition as a risk factor for left displacement of the abomasum in dairy cows. J. Am. Vet. Med. Assoc. 203:852-853.

Murray, R. D., J. E. Horsfield, W. D. McCormick, H. J. Williams, and D. Ward. 2008. Historical and current perspectives on the treatment, control and pathogenesis of milk fever in dairy cattle. Vet. Rec. 163:561-565.

NRC. 2001. Nutrient Requirements of Dairy Cattle. 7th rev. ed. National Academy Press, Washington, DC.

O'Driscoll, K., L. Boyle, and A. Hanlon. 2008. A brief note on the validation of a system for recording lying behaviour in dairy cows. Appl. Anim. Behav. Sci. 111:195-200.

Østergaard, S., and T. Larsen. 2000. Associations between blood calcium status at calving and milk yield in dairy cows. J. Dairy Sci. $83: 2438-2440$

Proudfoot, K. L., J. M. Huzzey, and M. A. G. Keyserlingk. 2009. The effect of dystocia on dry matter intake and behavior of Holstein cows. J. Dairy Sci. 92:4937-4944.

Quiroz-Rocha, G. F., S. J. LeBlanc, T. F. Duffield, D. Wood, K. E. Leslie, and R. M. Jacobs. 2009. Reference limits for biochemical and hematological analytes of dairy cows one week before and one week after parturition. Can. Vet. J. 50:383-388.

Rajala-Schultz, P. J., Y. T. Gröhn, and C. H. McCulloch. 1999. Effects of milk fever, ketosis, and lameness on milk yield in dairy cows. J. Dairy Sci. 82:288-294.

Ramberg, C. F. Jr., E. K. Johnson, R. D. Fargo, and D. S. Kronfeld. 1984. Calcium homeostasis in cows, with special reference to parturient hypocalcemia. Am. J. Physiol. 246:R689-R704.

Ramberg, C. F., G. P. Mayer, D. S. Kronfeld, J. M. Phang, and M. Berman. 1970. Calcium kinetics in cows during late pregnancy, parturition, and early lactation. Am. J. Physiol. 219:1166-1177.

Reinhardt, T. A., J. D. Lippolis, B. J. McCluskey, J. P. Goff, and R. L. Horst. 2011. Prevalence of subclinical hypocalcemia in dairy herds. Vet. J. 188:122-124.

SAS Institute. 2003. SAS User's Guide. Version 9.1. SAS Inst. Inc., Cary, NC. 